\title{
EFEKTIFITAS PEMBELAJARAN MENGGUNAKAN MOODLE TERHADAP MOTIVASI DAN MINAT BAKAT PESERTA DIDIK DI TENGAH PANDEMI COVID -19
}

\author{
Ervan Johan Wicaksana ${ }^{1}$, Pramana Atmadja ${ }^{2}$, Widya Lestari ${ }^{3}$, Luvita Agus Tanti ${ }^{4}$, dan Ririn Odrina ${ }^{5}$ \\ 1,3, 4, 5 Universitas Jambi \\ ${ }^{2}$ Universitas PGRI Madiun \\ e-mail: 1 ervan_jw@unja.ac.id_,2 pramana.atmadja@unipma.ac.id ; $3,4,5$ widyalestari2912@gmail.com
}

\begin{abstract}
Abstrak
Penelitian ini bertujuan untuk mengetahui motivasi dan minat bakat siswa dengan menggunakan moodle ditengah pandemi Covid-19. Aplikasi moodle dirasa dapat membantu peserta didik termotivasi untuk terus belajar ditengah merebaknya wabah Covid-19. Moodle adalah salah satu software open source e-learning yang dapat digunakan dalam proses pembelajaran. Kemudahan dalam penggunaan aplikasi ini yaitu dapat diakses melalui Android. Jenis penelitian ini adalah penelitian deskriptif kuantitatif. Metode pengumpulan data yang digunakan yaitu metode angket dan interview. Data didapatkan melalui pengisian angket yang disebar melalui email dan media sosial. Hasil penelitian ini mendapatkan data tentang beberapa kelebihan moodle dalam pembelajaran daring. Mayoritas mahasiswa berbakat dan terampil dalam menggunakan aplikasi e-learning moodle. Kesimpulannya diketahui adanya minat positif untuk mengikuti mata kuliah evaluasi proses dan hasil belajar biologi dengan menggunakan moodle. Mayoritas berperan aktif berdiskusi dalam mengikuti perkuliahan evaluasi proses dan hasil belajar biologi. Mahasiswa merasa aplikasi moodle menjadi jembatan antara aplikasi video conference dan media sosial.
\end{abstract}

Kata kunci: Evaluasi, Moodle, Motivasi, Minat, Covid-19

\begin{abstract}
This study aims to determine the motivation and interests of student talent by using moodle in the middle of the Covid-19 pandemic. The moodle application is thought to help motivated students to continue learning amid the outbreak of the Covid-19 outbreak. Moodle is an open source e-learning software that can be used in the learning process. The ease of use of this application can be accessed via Android. This type of research is quantitative descriptive research. Data collection methods used were questionnaire and interview methods. Data obtained through filling out questionnaires distributed via email and social media. The results of this study obtain data about some of the advantages of moodle in online learning. Many students are talented and skilled in using moodle e-learning applications. The conclusion is known to have a positive interest in taking the course evaluation of the biology learning process and outcomes using moodle. The majority plays an active role in discussions in the biology study process evaluation and learning outcomes. Students felt the moodle application became a bridge between the video conference application and social media.
\end{abstract}

Keywords: Evaluation, Moodle, Motivation, Interest, Covid-19.

\section{Pendahuluan}

Salah satu prinsip utama dalam proses pembelajaran adalah keaktifan peserta didik. Keaktifan peserta didik dalam proses pembelajaran sangat penting sebab keaktifan peserta didik menjadikan pembelajaran berjalan sesuai dengan perencanaan pembelajaran yang sudah disusun oleh pendidik, sehingga tujuan pembelajaran yang sudah dirumuskan akan tercapai. $28 \%$ animo belajar peserta didik dipengaruhi oleh adanya guru [1]. Proses pembelajaran dapat dikatakan sukses serta berkualitas apabila 
sebagian besar atau seluruhnya peserta didik terlibat secara aktif, baik fisik, sosial maupun mental dalam proses pembelajaran [2].

Keberhasilan proses kegiatan belajar dan mengajar dapat dilihat dari seluruh faktor yang berhubungan dengan pendidik dan peserta didik. Mulai dari perilaku pendidik dalam mengajar sampai dengan perilaku peserta didik sebagai timbal balik dari hasil sebuah pembelajaran. Sikap peserta didik pada saat sedang melaksanakan pembelajaran dapat mengindikasikan apakah peserta didik tersebut tertarik terhadap pelajaran yang sedang terlaksana atau malah sebaliknya. Ketertarikan peserta didik ini merupakan salah satu tanda minat [3].

Minat merupakan suatu motivasi intrinsik sebagai kekuatan pembelajaran yang menjadi daya penggerak seseorang dalam melakukan aktivitas dengan penuh kekuatan dan cenderung menetap, dimana aktivitas tersebut merupakan proses pengalaman belajar yang dilakukan dengan kesadaran yang penuh dan mendatangkan perasaan suka, senang, dan gembira. Sedangkan minat belajar itu sendiri dapat diartikan sebagai perhatian, rasa suka, dan rasa ketertarikan seseorang (peserta didik) terhadap belajar yang ditunjukkan adanya partisipasi, keinginan siswa untuk belajar dengan baik dan perhatian siswa dalam materi pelajaran secara aktif dan serius [4].

Peserta didik yang aktif dalam proses pembelajaran akan menciptakan suasana kelas menjadi lebih hidup dan kondusif, dimana masing- masing peserta didik dapat melibatkan kemampuannya semaksimal mungkin. Belajar yang bermakna terjadi bila peserta didik berperan secara aktif dalam proses belajar dan akhirnya mampu memutuskan apa yang akan dipelajari dan cara mempelajarinya. Dari aktivitas yang timbul dari peserta didik, maka menunjukkan bahwa adanya minat dan motivasi dari peserta didik itu sendiri [5].

Minat merupakan salah satu faktor yang dapat mempengaruhi usaha yang dilakukan seseorang. Minat yang terasa kuat akan menimbulkan usaha yang serius, gigih dan tidak mudah putus asa dalam menghadapi tantangan atau rintangan, Jika seorang peserta didik memiliki rasa ingin belajar, ia akan cepat mengerti dan mengingatnya [6].

Perkembangan Teknologi Informasi telah mendorong munculnya berbagai inovasi model pembelajaran dibidang pendidikan. Model pembelajaran inovatif berbasis teknologi tersebut muncul karena kendala yang terdapat pada metode pembelajaran tradisional, dimana peserta didik tidak dapat terlibat aktif dalam proses belajar mengajar dalam bentuk pertemuan fisik. Secara pembelajaran tradisional, lingkungan belajar mengacu pada sistem pembelajaran tatap muka, (teacher-directed learning). Peserta didik hanya bersikap reaktif terhadap lingkungannya, tetapi tidak berperan aktif dalam lingkungannnya.

Tujuan pendidikan dengan kemajuan teknologi dan pengetahuan berpengaruh terhadap proses pendidikan dan pengajaran, hal ini berakibat menuntut pendidik harus mampu menggunakan media. Media pembelajaran sering diartikan sebagai segala sesuatu yang dapat digunakan oleh pendidik untuk menyalurkan pesan pembelajaran (message learning), merangsang pikiran, perasaan, perhatian serta kompetensi peserta didik sehingga dapat memotivasi peserta didik dalam proses pembelajaran. Dari paparan tersebut media pembelajaran dapat diartikan sebagai sarana yang digunakan oleh pendidik dalam proses pembelajaran untuk memudahkan dalam penyampaian informasi atau transfer knowlage kepada peserta didik serta memotivasi agar terwujudnya pembelajaran yang efektif [7].

Salah satu media pembelajaran berbasis teknologi yang dapat dijadikan sebagai penunjang pada media yang sudah ada adalah dalam bentuk e-learning (pembelajaran elektronik). E-learning merupakan aplikasi internet yang dapat menghubungkan peserta didik dan pendidik dalam sebuah ruang belajar online. E-learning didesain untuk mengatasi keterbatasan antara pendidik dan pesrta didik, terutama dalam hal waktu, ruang kondisi, dan keadaan. Ringkasnya, e-learning dapat menciptakan sebuah ruang digital pembelajaran, dimana peserta didik dapat mengakses materi dari berbagai sumber tanpa dibatasi ruang dan waktu [8]. 
Saat ini dunia dikejutkan dengan mewabahnya suatu penyakit yang disebabkan oleh sebuah virus yang bernama corona atau dikenal dengan istilah covid-19. Akibat adanya pandemi covid-19 ini, menyebabkan diterapkannya berbagai kebijakan untuk memutus mata rantai penyebaran virus covid19 tersebut. Social distancing menjadi pilihan berat bagi setiap negara dalam menerapkan kebijakan untuk pencegahan penyebaran covid-19, karena kebijakan ini berdampak negatif terhadap segala aspek kehidupan.

Pembatasan interaksi sosial masyarakat dapat menghambat laju pertumbuhan dan kemajuan dalam berbagai bidang kehidupan, namun tidak ada pilihan lain, karena cara ini adalah yang paling efektif. Kebijakan Social Distancing berakibat fatal terhadap roda kehidupan manusia, masalah ekonomi yang paling terasa dampaknya, karena hal ini menyentuh berbagai lapisan masyarakat. Tak terkecuali dibidang pendidikan juga ikut terdampak kebijakan ini. Keputusan pemerintah yang mendadak dengan meliburkan atau memindahkan proses pembelajaran dari sekolah atau perguruan tinggi ke rumah membuat kewalahan banyak pihak. Peralihan pembelajaran ini memaksa berbagai pihak untuk mengikuti alur yang sekiranya bisa ditempuh agar pembelajaran dapat berlangsung, dan yang menjadi pilihan adalah dengan pemanfaatan teknologi sebagai media pembelajaran daring atau dengan model e-learning.

Terdapat banyak jenis aplikasi yang mendukung proses pembuatan media pembelajaran dengan model e-learning, salah satunya yaitu Moodle. Moodle merupakan suatu paket perangkat lunak yang dapat dimodifikasi /dimasukkan berbagai unsur multimedia baik berupa flash (animasi bergerak), audio (suara) ataupun video (gambar dan suara). Moodle diberikan secara gratis sebagai perangkat lunak open source. Artinya, meski perangkat tersebut memiliki hak cipta, moodle tetap memberikan kebebasan bagi pengguna untuk menggunakan dan memodifikasi sesuai dengan kebutuhan pengguna [9].

Moodle merupakan program open source yang paling terkenal diantara program-program elearning yang ada, misalnya atutor, Learning Management System (LMS) dan seterusnya. Aplikasi moodle ini pertama kali dikembangkan oleh Martin Dougiamas pada bulan Agustus tahun 2002 dengan Moodle versi 1.0. Moodle adalah singkatan dari Modulator Object Oriented Dynamic Learning Environment yang intinya pengajar dan peserta didik melakukan aktifitas pengajaran dalam aktivitas online [10].

Penggunaan aplikasi Moodle ini sangat membantu, terlebih lagi ditengah tengah situasi pandemi covid-19 ini yang mengharus kan jaga jarak atau social distancing, maka aplikasi moodle ini dapat digunakan sebagai solusi agar kegiatan belajar mengajar tetap berjalan dengan bagaimana mestinya. Dengan adanya aplikasi ini menjadikan alternatif bagi pengajar agar tetap dapat membagikan ilmunya tanpa harus melanggar kewajiban untuk jaga jarak, dan mahasiswa pun mendapatkan haknya untuk mendapat ilmu. Dengan adanya aplikasi ini membuktikan bahwa jarak tidak menghalangi sesuatu terutama dalam bidang pendidikan [11]. Dengan menggunakan aplikasi berbasis e-learning ini jarak yang jauh antara dosen dan mahasiswa selama pandemi covid ini dapat terbantu karena tim pengajar [12]. Terdapat fitur-fitur yang dapat membantu pada saat proses pembelajran berlangsung seperti contoh nya quiz, kolaborasi, penugasan dan komunikasi dan yang dapat meng-upload berbagai bentuk materi yang diberikan disebut sebagai fitur utama [13].

Dalam mata kuliah evaluasi proses dan hasil belajar Biologi belum pernah menggunakan media pembelajaran moodle. Dalam penelitian ini ingin menggali bagaimana respon mahasiswa khususnya dalam hal motivasi dan minat belajarnya. Dengan penggunaan aplikasi Moodle sebagai media pembelajaran Evaluasi Proses dan Hasil Belajar Biologi diharapkan kegiatan belajar mengajar akan lebih efektif. Meskipun banyak hasil penelitian menunjukkan bahwa efektifitas pembelajaran menggunakan sistem e-learning cenderung sama bila dibanding dengan pembelajaran konvesional atau klasikal. Akan tetapi terdapat keuntungan yang bisa diperoleh dengan e-learning adalah dalam hal fleksibilitasnya, khususnya pembelajaran ditengah pandemic covid-19. Tujuan dari penelitian ini adalah untuk mengetahui pertumbuhan minat dan motivasi peserta didik pada mata kuliah Evaluasi dan Hasil proses Belajar Biologi di tengah pandemi covid-19. 


\section{Metode Penelitian}

Jenis Penelitian ini yaitu deskriptif kuantitatif. Penelitian ini menggunakan metode Angket yang disebarkan melalui WhatsApp kepada seluruh Mahasiswa biologi yang pernah atau yang sedang memprogram Mata kuliah Evaluasi dan Hasil Proses Belajar Biologi di Universitas Jambi. Angket merupakan alat pengumpulan data atau informasi melalui daftar pertanyaan atau pernyataan tertulis yang telah disusun dan disebarkan kepada responden. Metode angket dalam penelitian ini bertujuan untuk mengukur minat dan motivasi belajar mahasiswa terhadap penggunaan Moodle sebagai media pembelajaran. Selain menggunakan angket, proses crosscek data juga dilakukan dengan menggunakan lembar wawancara (interview). Wawancara ini dilakukan untuk mengklarifikasi dan mendapatkan data lebih dalam lagi mengenai point-point yang diteliti.

Penelitian ini bertujuan untuk mengetahui keefektifitasan pembelajaran dengan menggunakan Moodle terhadap minat dan motivasi peserta didik pada mata kuliah Evaluasi Proses dan Hasil Belajar Biologi. Pengumpulan data diambil dari hasil tanggapan atau respon terhadap angket yang telah disebarkan. Data hasil akan disajikan dalam bentuk Tabel. Analisis data yang dilakukan bertujuan untuk memberi makna terhadap data yang telah dikumpulkan. Hasil penelitian yang akan dianalisis secara deskriptif adalah data angket minat dan motivasi belajar mahasiswa terhadap penggunaan media pembelajaran Moodle.

\section{Hasil dan Pembahasan}

Dalam aplikasi Moodle terdapat beberapa komponen dengan fungsi yang berbeda-beda yang dapat mendukung proses pembelajaran. Komponen-komponen tersebut meliputi Activities (Aktivitas), Search Forum (Pencarian Forum), Administration (Administrasi) dan Course Categories (Kategori Pelajaran). Setiap komponen moodle memiliki fungsi yang berbeda-beda untuk mengembangkan moodle sesuai dengan pengguna inginkan. [14]

Moodle memiliki kelebihan dan kekurangan. Adapun kelebihan dari aplikasi moodle [15] yaitu:

a) Semua orang dapat mengunduh software moodle di internet secara gratis dari situs resminya.

b) Mudah untuk digunakan, moodle dirancang sedemikian rupa sesuai dengan kebutuhan proses pembelajaran.

c) Proses instalasi yang mudah

d) Tersedianya fasilitas kuis, tugas, dan pemberian nilai yang dapat diatur sesuai kebutuhan.

e) Memiliki daya tampung peserta didik yang banyak.

f) Cocok digunakan untuk media ajar online

g) Mendukung beberapa type file yang dapat digunakan untuk proses pembelajaran.

h) Memuat struktur materi pengajaran yang rapi dan dapat dibuat dalam beberapa kategori.

i) Tersedianya paket bahasa yang dapat dipilih sesuai dengan kebutuhan.

j) Dapat mengganti tampilan situs karena dilengkapi dengan menu ganti themes.

Adapun kekurangan dari aplikasi Moodle [16] yaitu:

a) Waktu akses yang lambat karena bandwidth yang kecil dan buruknya perancangan materi yang memiliki ukuran file yang besar.

b) Kurang dapat memenuhi kebutuhan pengguna yang disebabkan oleh buruknya perancangan aplikasi web learning sehingga tidak sesuai dengan kebutuhan pengguna.

c) Para pengguna tidak mengetahui dan mengenal secara baik sistem yang dari pandangannya sendiri, orientasi menurut bagaiman ia melihat sesuatu.

Pada saat ini telah banyak perguruan tinggi yang memakai aplikasi Moodle sebagai media pembelajaran. Moodle merupakan salah satu media pembelajaran yang dapat diterapkan dalam proses pembelajaran Evaluasi Proses dan Hasil Belajar Biologi. Evaluasi Proses dan Hasil Belajar Biologi merupakan salah satu Mata Kuliah di program Studi Pendidikan Biologi di Universitas Jambi. Dilihat dari komponen yang dimiliki, Moodle memiliki fitur yang dapat dimanfaatkan untuk menyampaikan 
berbagai materi Evaluasi Proses dan Hasil Belajar Biologi. Fitur- fitur yang dapat dimanfaatkan sebagai penunjang pembelajaran yaitu misalnya: tugas, kuis, komunikasi, kolaborasi, serta fitur utama yang dapat mengupload berbagai format materi pembelajaran. Oleh sebab itu, penyampaian materi tersebut akan lebih mudah dan menarik karena terdapat fitur yang mendukung kegiatan belajar mengajar, sehingga tujuan dari pembelajaran dapat tercapai.

Kelompok eksperimen memanfaatkan e-learning untuk proses pembelajaran. Dengan hal itu sangat membawa pengaruh yang positif terhadap peserta didik karena motivasi dalam belajarnya meningkat. Berbeda hal nya dengan proses belajar pada kelompok kontrol yang masih menggunakan LCD proyektor sebagai alat bantu dalam proses pembelajaran dan materi presentasi [17].

Dari hasil Angket yang telah disebarkan didapatkan 8 tanggapan dari Mahasiswa Biologi dari kelas regular B, dan kelas regular C. Adapun hasil yang didapat yaitu:

Tabel 1. Data Minat Bakat dan Motivasi

\begin{tabular}{|c|l|l|l|l|l|}
\hline NO. & $\begin{array}{c}\text { SUBYEK } \\
\text { PENELITIAN }\end{array}$ & $\begin{array}{c}\text { JENIS } \\
\text { KELAMIN }\end{array}$ & MINAT & BAKAT & \multicolumn{1}{|c|}{ MOTIVASI } \\
\hline 1. & Mahasiswa 1 & Perempuan & Biasa saja & Mahir & Biasa saja \\
\hline 2. & Mahasiswa 2 & perempuan & Berminat & Mahir & Termotivasi \\
\hline 3. & Mahasiswa 3 & Perempuan & Biasa saja & Mahir & Sangat termotivasi \\
\hline 4. & Mahasiswa 4 & Perempuan & Berminat & Mahir & Sangat termotivasi \\
\hline 5. & Mahasiswa 5 & Perempuan & Berminat & Mahir & Termotivasi \\
\hline 6. & Mahasiswa 6 & Perempuan & Berminat & Mahir & Sangat termotivasi \\
\hline 7. & Mahasiswa 7 & Perempuan & Berminat & Mahir & Sangat termotivasi \\
\hline 8. & Mahasiswa 8 & Laki- Laki & Berminat & Mahir & Sangat termotivasi \\
\hline
\end{tabular}

Berikut penjabaran dan pembahasan mengenai data yang tersaji dalam tabel 1:

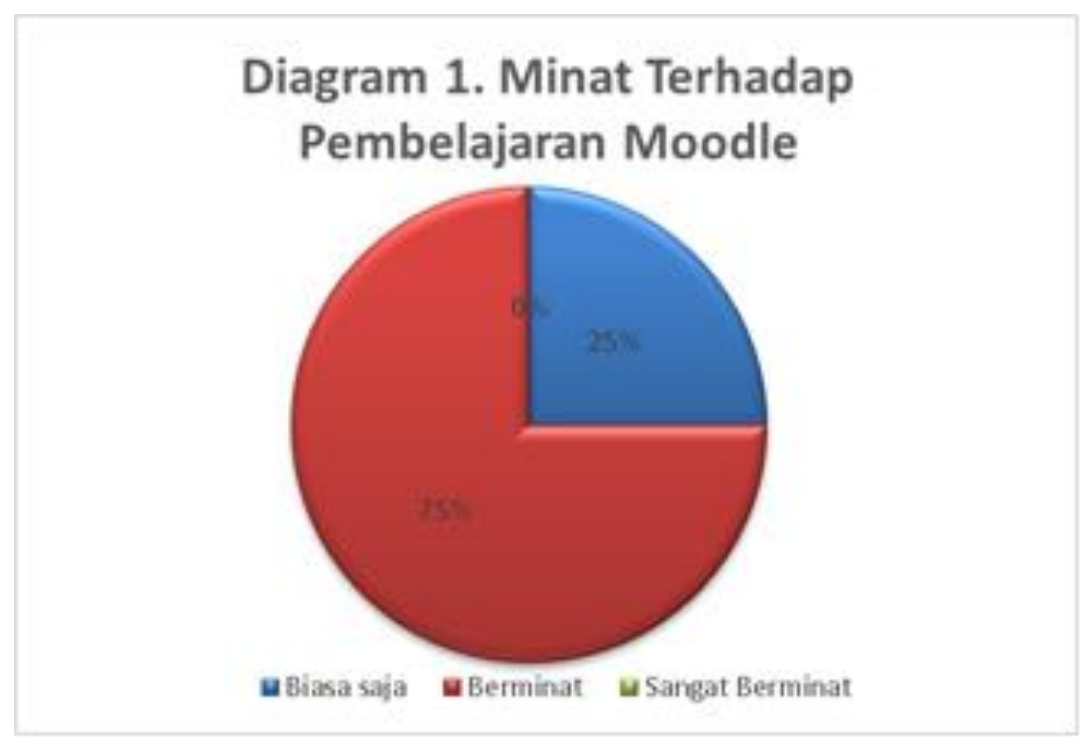


Diagram 1 disamping menunjukkan bahwa $75 \%$ mahasiswa berminat dalam pembelajaran online menggunakan moodle. Merebaknya wabah Covid-19 ini menuntut para pebelajar untuk menggunakan aplikasi-aplikasi e-learning. Mau tidak mau mahasiswa harus menggunakannya untuk proses perkuliahan. Dengan adanya himbauan belajar dari rumah juga membuat mahasiswa berminat untuk menggunakan e-learning khususnya moodle. Walaupun ada $25 \%$ mahasiswa yang biasa saja dalam minat menggunakan moodle.

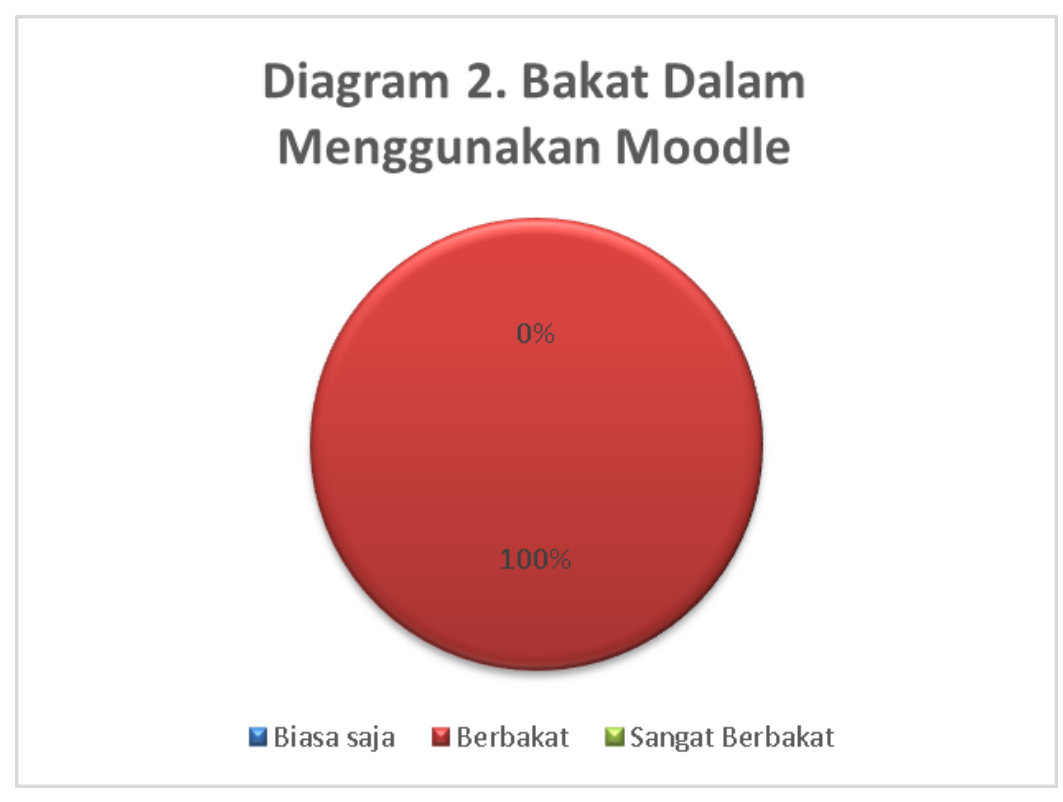

Data diagram 2 menunjukkan data bahwa kemudahan mahasiswa dalam menggunakan aplikasi moodle. Data ini mempunyai makna bahwa tidak ada satupun mahasiswa yang mengalami kesulitan ketika menggunakan aplikasi moodle. Padahal mahasiswa baru pertama kali menggunakan aplikasi moodle ini. Mereka belajar secara otodidak. Tidak ada pelatihan khusus dalam menggunakannya. Moodle memang didesain mudah digunakan (user friendly), akan tetapi dalam penggunaannya perlu pengetahuan dan keterampilan dasar yang harus dimiliki terlebih dahulu. Dalam penelitian ini juga digali informasi-informasi yang membuat mereka berbakat dalam menggunakannya. Diantaranya adalah kemampuan mengoperasikan computer, pengetahuan dalam memahami aplikasi, khususnya menu-menu, serta pengetahuan dan keterampilan mengunggah dan mengunduh file.

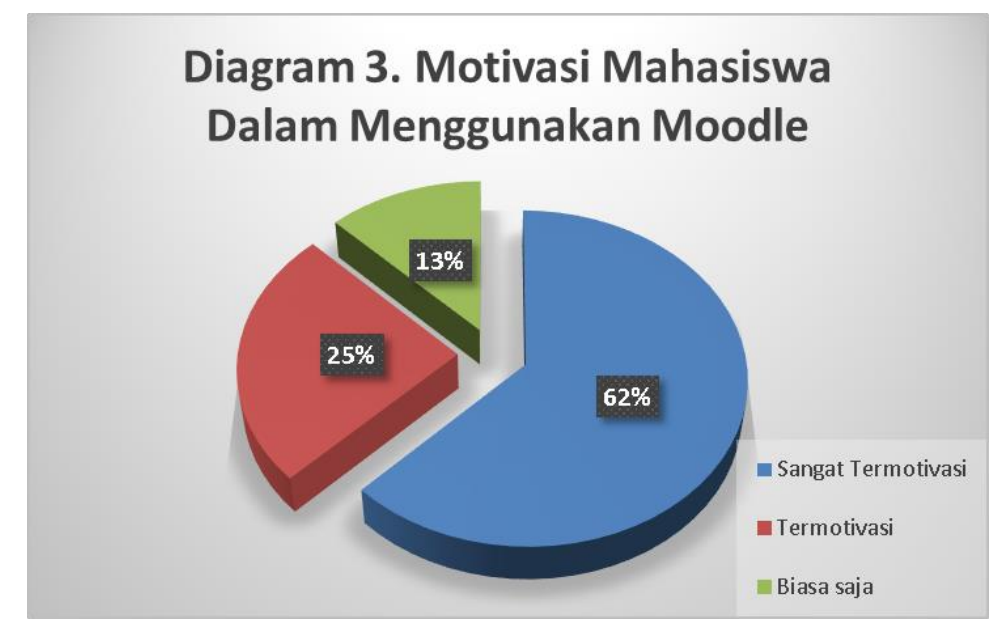

Diagram di atas menunjukkan bahwa mayoritas mahasiswa sangat termotivasi dalam menggunakan moodle. Sebanyak $62 \%$ mahasiswa merasa sangat termotivasi untuk kuliah daring ketika 
menggunakan moodle. $25 \%$ mahasiswa merasa termotivasi. Dalam penelusuran data melalui interview didapatkan keterangan bahwa terdapat beberapa alasan kenapa mereka menjadi termotivasi. Alasan tersebut diantaranya adalah karena dalam pembelajaran daring, mayoritas pengajar menggunakan aplikasi media sosial grup WhatsApp. Selain itu pengajar terkadang juga menggunakan aplikasi zoom cloud meeting dalam menjelaskan. Menurut keterangan, mayoritas dari mereka sangat jenuh dan kurang paham ketika kuliah menggunakan aplikasi WhatsApp. Ketika Menggunakan aplikasi video conference zoom meeting mereka juga merasa kurang bersemangat karena terkendala kuota. Kuota yang dibutuhkan dalam menggunakan zoom meeting sangat besar bagi mahasiswa. Mereka merasa keberatan serta terkadang ada beberapa mahasiswa yang tidak mendapatkan cukup sinyal dalam menggunakan aplikasi tersebut. Di tengah kebosanan mereka mendapatkan satu alternative aplikasi yang digunakan untuk pembelajaran, yaitu aplikasi moodle. Aplikasi moodle ini dirasa oleh mahasiswa menjadi jembatan antara aplikasi video conference dan media sosial. Hampir semua mahasiswa berperan aktif berdiskusi dan memberikan feed back dalam mengikuti perkuliahan evaluasi proses dan hasil belajar biologi menggunakan moodle.

\section{Kesimpulan}

Kesimpulan dari hasil penelitian ini yaitu didapatkan hasil minat positif untuk mengikuti mata kuliah evaluasi proses dan hasil belajar biologi dengan menggunakan Moodle. Banyak mahasiswa berperan aktif berdiskusi dan memberikan feed back dalam mengikuti perkuliahan evaluasi proses dan hasil belajar biologi. Aplikasi moodle dirasa oleh mahasiswa menjadi jembatan antara aplikasi video conference dan media sosial. Moodle tidak memerlukan banyak kuota dan juga bisa digunakan interaktif.

Saran dari penelitian ini, sebaiknya proses pembelajaran menggunakan aplikasi yang dapat menumbuhkan minat dan motivasi peserta didik untuk mengikuti pembelajaran. Selain aplikasi moodle, banyak aplikasi lainnya yang dapat digunakan sebagai media pembelajaran contohnya google classroom, edmodo dan lain sebagainya.

\section{Daftar Pustaka}

[1] Wicaksana E.J., Atmadja Pramana. 2018. Analisis Dampak Program Guru Pendamping Direktorat PSMK (Program SM3T) Terhadap Animo Belajar Peserta Didik Pada Mata Pelajaran Biologi Di SMKN 1 Kintamani, Bali. Biodik Vol.4 No.2 Desember 2018: 110119.

[2] Mulyasa. 2005. Kurikulum Berbasis Kompetensi: Konsep, karakteristik dan Implementasi. Bandung: RemajaRosdakarya.

[3] Irwanto. 2002. Psikologi Umum. Jakarta: PT. Prenhallindo.

[4] Wasty soemanto.1990. Psikologi Pendidikan. Jakarta: Rineka Cipta.

[5] Eveline Siregrar, Hartini Nara,2015. Teori Belajar dan Pembelajaran. Bogor: Ghalia Indonesia

[6] Ngalim Purwanto. 2007. Psikologi Pendidikan. Bandung: PT. Remaja Rosdakarya.

[7] Novan Ardy Wiyani. 2013. Desain Pembelajaran Pendidikan. Yogyakarta: Ar-Ruzz Media.

[8] Deni dermawan. 2016. Pengembangan E-learning Teori dan Desain. Bandung: Remaja Rosda Karya.

[9] Amiroh. 2012. Kupas Tuntas Membangun E-learning dengan Management Sistem. Jakarta: Berkah Mandiri Globalindo. 
[10] Suartama Kadek, Dewa kade sastra. 2014. E-learning berbasis Moodle. Yogyakarta: Graha Ilmu.

[11]Belina E. 2013. Perancangan Dan Implementasi Aplikasi E -Learning Versi Mobile Berbasis Android. Jurnal Singuda Ensikom. 4(3):76-81.

[12] Syamsul Rizal, Birrul Walidain. 2019. Pembuatan Media Pembelajaran E-Learning Berbasis Moodle pada Matakuliah Pengantar Aplikasi Komputer Universitas Serambi Mekkah. Jurnal Ilmiah DIDAKTIKA. Vol. 19, No., 178-192

[13] Surjono H D. 2011. Membangun Course E-Learning Berbasis Moodle. Yogyakarta: UNY Press.

[14] Radana dvorak. 2011. Moodle for Dummies. Indiana: Wiley Publishing.

[15] Kurniawan Rulianto. 2009. Membangun Media Ajar Online untuk Orang Awam. Palembang: Maxikom.

[16] Setiawan Wawan. 2006. Pembelajaran Berbasis ICT: Model E-Learning Menggunakan Opensource Moodle Dalam Buku, Mimbar Pendidikan. Jakarta: Penerbit UPI Press.

[17] Samsuddin. 2013. Pemanfaatan E-Learning Moodle pada Mata Pelajaran Matematika di SMKN 5Makassar Jurnal Komunikasi KAREBA 2(1): 65-72. 